\section{NAVEGANDO PELOS MEANDROS DO RIO DAS CONTAS}

CHIAPETTI, Rita Jaqueline Nogueira. Na beleza do lugar, o rio das Contas indo... ao mar. Ilhéus, BA: Editus, 2014. 212p. ISBN: 978-85-7455-351-1

\section{Tiago Vieira Cavalcante'}

O livro "Na beleza do lugar, o rio das Contas indo... ao mar" de Rita Jaqueline Nogueira Chiapetti, professora da Universidade Estadual de Santa Cruz - UESC, na Bahia, é fruto de sua tese de doutorado, defendida no ano de 2009, no programa de Pós-Graduação em Geografia da Universidade Estadual Paulista - UNESP, em Rio Claro, sob a orientação da Professora Emérita Dra. Lívia de Oliveira. Livro onde geograficidade, afetividade e poesia se combinam para revelar os meandros daquele que é o maior rio inteiramente baiano, o rio das Contas.

O rio das Contas nasce na Serra da Tromba, no município de Piatã, borda ocidental da Chapada Diamantina e tem a sua foz em Itacaré, cidade litorânea turística no sul da Bahia e, como todo rio, tem grande importância para as pessoas que vivem nas proximidades de suas margens. Chiapetti concentra seu estudo no trecho do rio que está inserido no município de Itacaré, ampliando "o conhecimento sobre a relação que as pessoas de Itacaré têm com o seu lugar" (CHIAPETTI, 2014, p. 22). Ao se preocupar com a maneira como as pessoas vivenciam e valoram os lugares, as formas como os itacareenses se relacionam com o rio das Contas, a autora contribui com as discussões realizadas no âmbito da Geografia Humanista, pautadas na multiplicidade de experiências geográficas que o ser humano tem sobre a Terra.

No primeiro capítulo, "Conhecendo... o rio das Contas", a autora revela a história e geografía deste rio, contando sobre os diferentes modos como foi apropriado ao longo do tempo e apresentando as características de suas diferentes paisagens, pois como indica, é importante "conhecermos os lugares que estamos estudando, principalmente se formos perguntar às pessoas que moram nestes lugares o que significam (para elas) determinadas

1 Doutorando em Geografia, UNESP (Rio Claro). tiagogeografia@yahoo.com.br.

$\triangle$ Instituto de Geociências e Ciências Exatas, Universidade Estadual Paulista. Avenida 24A, 1515, Jardim Bela Vista, Rio Claro, SP. 13506-900.

\section{Rita Jaqueline Nogueira Chiapetti}

\section{Na beleza do lugar, 0 rio das Contas}

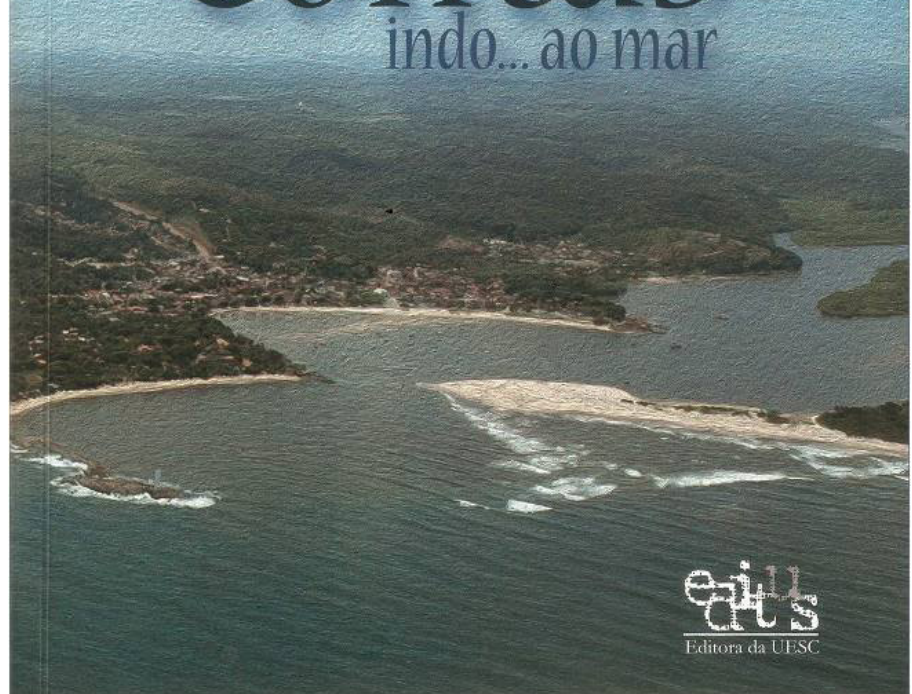

coisas ao seu redor" (CHIAPETTI, 2014, p. 27). Desse modo, tomando como base a bacia hidrográfica do rio das Contas, a autora esboça as características geomorfológicas, climatológicas, hidrológicas e vegetacionais que o compõem. Relacionando a estas características geográficas, Chiapetti delineia como o gado, a cana-de-açúcar, o ouro, o diamante e o cacau foram, cada um ao seu tempo, riquezas importantes nas relações 
socioeconômicas e culturais entre as pessoas e o rio. Assim, acabamos por conhecer mais sobre as diferentes gentes que passaram por lá: indígenas, escravos negros, bandeirantes, garimpeiros, fazendeiros e mesmo piratas que furtavam aqueles que extraiam riquezas provenientes das águas do rio das Contas.

Mas é no segundo capítulo, "Percebendo... o rio das Contas", que a autora evidencia as geograficidades inerentes à compreensão do rio, os significados atribuídos às suas águas, que por isso o tornam lugar. Como salienta: "Mais que um rio, o Contas sempre foi um lugar para os habitantes do município de Itacaré, no sul da Bahia, pois um local se torna um lugar na medida em que o ser humano Ihe atribui significado" (CHIAPETTI, 2014, p. 82). Temos no poema escrito por Otília Maria Nogueira, moradora de Itacaré, com o qual Chiapetti ilustra o seu livro, um belo e importante exemplo do quanto o rio é relevante para a vida da população que dele usufrui, alimentando a imaginação geográfica daqueles que orientam o seu cotidiano a partir dele. Laços topofílicos entremeados e enriquecidos por relatos e poesias que exploram o lado simbólico e afetivo das pessoas para com o rio, pois "A afetividade permeia todo o processo de compreensão do pensamento humano na sua dimensão consciente e, inclusive, na sua dimensão inconsciente" (CHIAPETTI, 2014, p. 100).

Diante de toda a riqueza de detalhes sobre a natureza e cultura que envolve o rio das Contas, Chiapetti apresenta no terceiro capítulo, "Vivenciando... o rio das Contas", o trabalho de campo que realizou em busca dos diferentes significados que os moradores de Itacaré atribuem ao rio. Para isso, a autora explora o mundo vivido de quarenta e um itacareenses a partir de entrevistas e organiza em quatro categorias as diferentes opiniões e sentimentos que eles têm pelo rio, quais sejam: trabalho, subsistência, pertença e alegria.
Cada uma destas categorias evidencia o quanto o rio das Contas é multifacetado, consistindo para alguns o seu lugar de labuta, de sustento, de retirada de alimento e para outros um lugar de pertença, de alegria, de divertimento. Esclarece também a relação inextricável dos itacareenses com o rio, relação ontológica que funda a geografia que os envolve, enfim... a geografia do lugar.

No último capítulo, "Ao finalizar, o rio as Contas chegando... ao seu destino", a autora chama a atenção para o aumento do fluxo turístico em Itacaré, facilitado pela pavimentação da rodovia BA-001, trecho Ilhéus-Itacaré, mas fomentado pela beleza cênica de sua paisagem. Lembra dos benefícios que o turismo traz como o aumento da oferta de empregos, mas também adverte sobre as possíveis degradações ambientais e sociais que a atividade pode provocar. Vale pensarmos que, se o turismo é uma atividade que, fundamentalmente, "consome paisagens", estas paisagens, como salienta a autora, devem ser normatizadas e fiscalizadas pelo poder público, assim como conservadas/preservadas pela população que não deve valorizar somente a natureza do lugar, mas também toda a cultura que o envolve.

Ao conhecer, perceber e vivenciar o rio das Contas, Chiapetti nos brinda com um livro recheado de atributos. Livro onde aprendemos a olhar de uma maneira singular para os rios: enamorada, curiosa e sem distanciamentos. Livro onde não são dissociados os conhecimentos oriundos da geografia física daqueles da geografia humana, onde a geografia é pensada e elaborada em sua integralidade. Livro onde são consideradas fundamentais as experiências humanas com os rios, ligação visceral dos homens com esses corpos d'água, para uma compreensão geográfica humanista dos rios, qualquer rio... o rio das contas. $\theta$ 